\title{
Irena Medňanská - vyorala brázdu a naplnila srdcia budúcich generácií láskou k hudbe
}

\author{
Nečakaný odchod inšpiratívnej osobnosti
}

\section{Slávka Kopčáková}

Muzikologička, pedagogička, reprezentantka slovenskej hudobnej pedagogiky v európskom kontexte, manažérka kultúry, organizátorka hudobného života v regióne východného Slovenska a publicistka Irena Medňanská, rod. Glogovská (28. 7. 1950, Považská Bystrica - 31. 12. 2020, Prešov), sa svojou vytrvalou teoretickou a organizačnou aktivitou zaradila medzi popredné osobnosti slovenskej hudobnej kultúry a európskej hudobnej pedagogiky. Absolventka Vysokej školy hudobnej Franza Liszta vo Weimare (1973 - 1977) v odbore hra na akordeóne a súčasne aj pedagogička v Hudobnej škole v Sonderhausene v bývalej NDR (1973 - 1980) sa na Slovensko vrátila s vynikajúcou profesionálnou a odbornou výbavou. Vdaka nej nasledujúce štyri dekády svojho profesionálneho života pomáhala formovat’ tvár hudobnej kultúry a obhajovat' záujmy hudobnej a estetickej

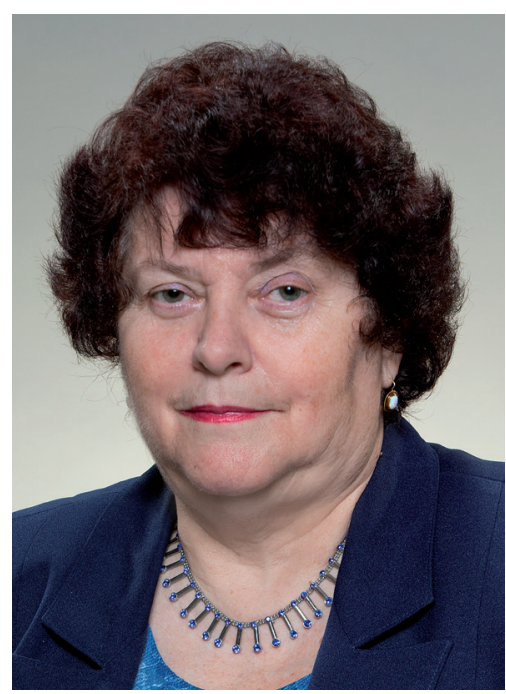

prof. Irena Medňanská (2019) výchovy, čo sa stalo jej celoživotným programom.

V rokoch 1987 - 1993 absolvovala doktorandské štúdium v odbore Vedy o umení (Teória a dejiny hudby, nostrifikované v SR) na Univerzite Martina Luthera v Halle. Jej školitelom bol významný nemecký muzikológ a propagátor detského zborového umenia, skladatel' hudby pre deti, prof. Siegfried Bimberg. Ten vo výraznej miere určil jej budúcu bádatel'skú orientáciu. V tom čase vyšla tlačou aj prvá z jej dvoch význam- 
ných monografií Kinderchormusik aus dem Schaffen slowakischer Komponisten nach 1945 (1993).

Zakrátko po zmene spoločensko-politických pomerov u nás jej jazyková výbava umožnila nastúpit cestu nielen k vedeckej práci, ale aj smerom k organizačnému zastrešeniu a zastupovaniu záujmov hudobnej výchovy v širšom nadnárodnom kontexte. Irena Medňanská rokoch 1992 - 2009 reprezentovala Slovensko v prezídiu Európskej asociácie pre školskú hudobnú výchovu (EAS), v rokoch 2009 - 2018 bola národnou koordinátorkou, v roku 2016 jej udelili doživotné čestné členstvo v prezídiu.

Slovenskú hudobnú pedagogiku nielen zastupovala a propagovala, ale tejto vedeckej disciplíne, jej aplikáciám (hudobná výchova, umelecká výchova, estetická výchova, hudobná edukácia) a jej učitelom, študentom, teoretikom a i. doslova „otvárala“ okná do Európy. V roku 1993 spolu so skladatel'om a pedagógom Jurajom Hatríkom stála pri zrode Asociácie učitelov hudby Slovenska (AUHS). Vybudovanie tejto organizácie umožnilo jej okamžité začlenenie do štruktúr International Society for Music Education (ISME) a European Association for Music in Schools (EAS) vd'aka individuálnemu členstvu koordinátorky. Za tri dekády činnosti v týchto združeniach (medzi rokmi 1992 - 2018) Irena Medňanská nevynechala takmer žiadny z kongresov, zväzových konferencií, interrim kongresov, kde Slovensko reprezentovala t’ažiskovými referátmi prevažne v plenárnych sekciách rokovaní. Stála aj pri vzniku Slovenskej Orffovej spoločnosti (SOS) v roku 1999, ked' na základe svojich skúseností a kontaktov pomáhala jej predsedníčke Miroslave Blažekovej pri jej založení. Táto spoločnost’ do dnešných dní potvrdzuje univerzálnost’ hudobného jazyka bez ohladu na rôznorodost’ krajín, národov a ich jazykov. Každoročné medzinárodné letné kurzy Orffovej spoločnosti sa tešia vel'kej pozornosti domácich a zahraničných frekventantov.

V roku 2000 sa Irena Medňanská úspešne habilitovala na Vysokej škole múzických umení v Bratislave vo vednom odbore Hudobné umenie - teória hudby. Titul docentky získala obhajobou habilitačnej práce Hudobná pedagogika na Slovensku, v nemeckej jazykovej oblasti a v celoeurópskom kontexte. Už tu sa profilovali jej záujmy o teoretické problémy hudobnej pedagogiky dynamizované paralelne jej aktivitami v AUHS a EAS, prinášajúcimi mnohé empirické zistenia a možnosti komparácie, čím si jej vedecká práca udržiavala kontakt s realitou hudobnoedukačnej praxe. O dekádu neskôr sa v roku 2011 úspešne inaugurovala na Ostravskej univerzite v Ostrave vo vednom odbore Hudobná teória a pedagogika (titul profesorka získala v roku 2012). Inauguračná prednáška mala názov Európska dimenzia hudobnej pedagogiky. Súčastou tohto úsilia bolo vydanie jej druhej vedeckej monografie Systematika hudobnej pedagogiky (2010).

Osobnostnú univerzálnost' pri prijímaní životných výziev a pracovných príležitostí môžeme dokladovat’ výberom pracovísk a pracovných pozícií, ktoré prijala. Pôsobila ako odborná asistentka na Katedre hudobnej výchovy na Pedagogickej fakulte v Nitre (1980 - 1981), odborná asistentka na Katedre hudobnej výchovy Pedagogickej fakulty UPJŠ v Prešove (1981 - 1988), riaditel'ka Štátnej filharmónie Košice (ŠfK) v Košiciach (1988 - 1991). Po návrate do Prešova od roku 1991 pôsobila nasledujúce tri dekády už nepretržite na Prešovskej univerzite. Na Katedre hudobnej výchovy Pedagogickej fakulty UPJŠ v Prešove (1991 - 1997) ako vedúca katedry, na fakulte ako prodekanka pre zahraničné vztahy. V roku 1997 aktívne participovala na vzniku Prešovskej univerzity (PU) so sídlom v Prešove a v rámci nej aj na vzniku Fakulty humanitných 


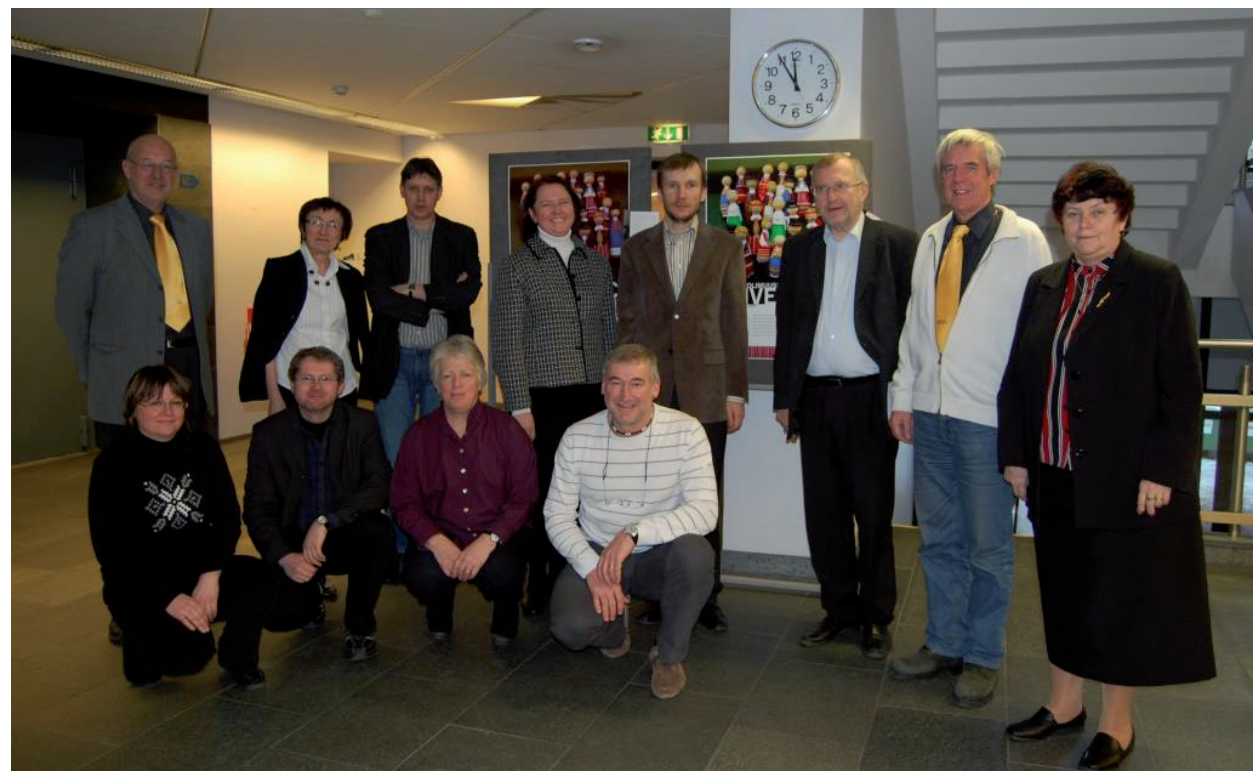

Prof. Irena Medňanská (prvá sprava) na konferencii EAS v Talline v roku 2009 spolu s bývalým prezidentom EAS prof. Franzom Niermannom (druhý sprava), s vtedy novou prezidentkou EAS prof. Sarah Henessy z Vel'kej Británie (tretia zl'ava dole), s bývalým prezidentom EAS prof. Josephom Scheideggerom (hore prvý zlava) a národnými koordinátormi EAS.

a prírodných vied (FHPV) ako jej súčasti, kde ako vedúca Katedry hudobnej výchovy pôsobila nad’alej. Po organizačných zmenách sa v roku 2010 stala riaditel'kou Inštitútu hudobného a výtvarného umenia Filozofickej fakulty PU. Paralelne s tým ako odborná asistentka pedagogicky pôsobila na oddelení hudby Katedry humanitných a sociálnych vied Fakulty prírodných vied Žilinskej univerzity v Žiline (2000 - 2003), kde pomáhala pri etablovaní nových študijných programov pre učitelov základných umeleckých škôl. Pedagogicky pôsobila aj v zahraničí ako mimoriadna profesorka na Univerzite v Rzeszowe (Instytut Muzyki Uniwersytetu Rzeszowskiego, 2003 - 2015), neskôr aj ako členka Akreditačnej komisie v Pol'sku a školitel'ka doktorandov v Českej republike (Olomouc, Ostrava) a v Pol'sku. V rokoch 2000 - 2016 pracovala ako metodička pre hudobnú výchovu na Metodicko-pedagogickom centre v Prešove, garantka a lektorka programov kontinuálneho vzdelávania učitelov. Je až neuveritel'né, kol'ko práce možno vykonat' za jeden l'udský život.

Už na konci prvej dekády nového milénia sa Irena Medňanská postupne vyprofilovala na jednu z vedúcich osobností našej hudobnej pedagogiky ako autorka početných vedeckých a odborných prác v tomto odbore, členka poradných orgánov pre hudobnú edukáciu, vyhladávaná expertka na legislatívne otázky. Takmer štyri dekády svojej tvorivej práce (okrem 3 rokov manažovania profesionálneho hudobného telesa) zasvätila Prešovskej univerzite ako pedagogička, neúnavná organizátorka umeleckej činnosti a aktivít pedagógov i študentov doma a v zahraničí. Organizovala vedecké konferencie a kongresy na pôde univerzity. Podujatím s vynikajúcim ohlasom u učitel'ov aj odborníkov v jej gescii bolo organizovanie šiestich 
cyklov seminárov a kolokvií Prešovské hudobno-pedagogické fórum (2004 - 2011) a sesterského podujatia 15 ročníkov Pedagogickej dvorany na VŠMU v Bratislave v gescii prof. Juraja Hatríka. Práve tieto podujatia plynule prešli do školskou reformou legislatívne ukotvených foriem kontinuálneho celoživotného vzdelávania učitelov hudby a učitel'ov hudobnej výchovy.

Za jej najvýznamnejší projekt, ktorý dodnes predstavuje pretrvávajúci stredoeurópsky model efektívnej a zmysluplnej akademickej kooperácie, možno považovat' „Most k spolupráci“ (1995 - 2001). Priniesol významné rozvojové a dynamizujúce impulzy pre všetky slovenské univerzity vychovávajúce budúcich učitelov hudobnej (resp. aj všeobecnejšie estetickej) výchovy. Jeho ideovým a ludským jadrom bola intenzívna spolupráca na osi Praha-Prešov, medzi pedagogickými fakultami Univerzity Karlovej a Prešovskej univerzity, reprezentovaná osobnost'ou Ireny Medňanskej a Miloša Kodejšku. Projekt mal zásadný význam pre napojenie sa na európske a svetové hudobné organizácie a viedol k udalosti medzinárodného významu, ked'sa pod identickým názvom uskutočnil na Slovensku (Prešove) medzinárodný kongres EAS ako v prvej z krajín bývalého socialistického bloku. Projekt "Most k spolupráci" obnovený pod novými

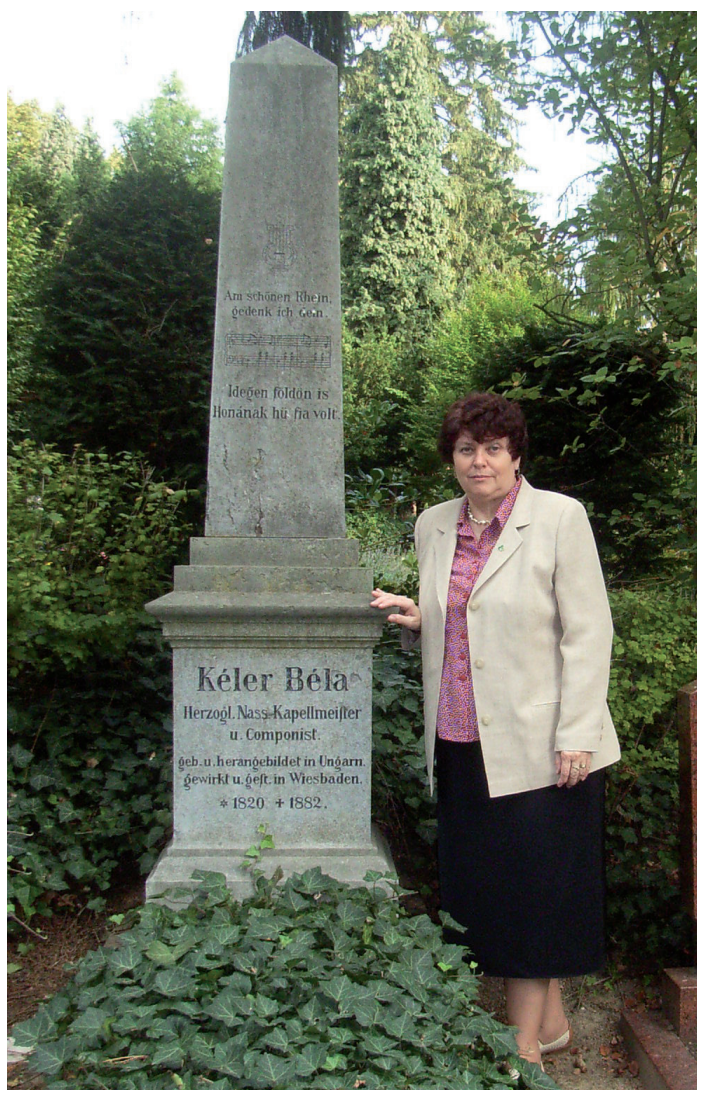

Po stopách bardejovského skladatela Bélu Kélera (1820 - 1882) vo Wiesbadene v roku 2006 (200. výročie narodenia bardejovského skladatel'a) názvami v rokoch 2002 - 2008 položil pevné základy pre odborovú kooperáciu krajín V4 vo vzdelávacej oblasti (postupne sa pridali univerzity v Pol'sku a Mad'arsku). Vd’aka ich spoločnému projektu Visegrad Fund, seminárov a spoločných umeleckých akademických podujatí, sa tieto aktivity od roku 2009 pretransformovali do série medzinárodných konferencií „Teorie a praxe hudební výchovy“ v Prahe.

Prácu Ireny Medňanskej v prospech slovenského školstva, vedy a hudobnej kultúry ani zd’aleka nereprezentuje len rozsiahle vedecké dielo, okrem knižných prác roztrúsené v stovkách štúdií a odborných článkov (vyše 330). Stojí za ňou aj pedagogická a organizačná práca $v$ akademickom prostredí. Jej výsledkom boli stovky dobre pripravených absolventov, ktorí sa stali učitel'mi hudobnej výchovy, rovnako i akademický dorast (dovedna 24 doktorandov) vyškolený na univerzitách na Slovensku, v Českej republike a v Pol'sku. 
Výrazná prítomnost’ organizačných kompetencií a kreativity sa prejavila aj v oblasti hudobného života. Irena Medňanská svoje nadanie pre kultúrny manažment zúročila okrem riadenia profesionálneho telesa aj v organizovaní vedeckých, umeleckých či spomienkových podujatí, ktorých cielom bolo objavovanie a propagácia hudobných tvorcov regiónu (Mikuláš Moyzes, Béla Kéler, Jozef Grešák a d’.). Sprístupňovanie a šírenie hudobnej tvorby skladatel'ských osobností regiónu prerástlo do mnohých živých hudobných realizácií vo východoslovenskom regióne (Košice, Prešov, Bardejov, Levoča, Sabinov a i.). Tieto podujatia obohatili hudobný život regiónu o hodnotné interpretačné (aj premiérové) stvárnenia hudobných diel celého radu slovenských skladatelov (Jozef Podprocký, Ladislav Burlas, Milan Novák, Mikuláš Moyzes, Béla Kéler a d'.).

Ak chceme komplexne predstavit’ profesionálnu cestu a výsledky celoživotnej práce Ireny Medňanskej, nemôžeme obíst' ani možnost' pozriet' sa na ňu cez optiku jej osobnostnej výbavy. Práve tá ju predurčila na úspešnú profesionálnu realizáciu, a to najmä vd’aka schopnosti prirodzene sa pohybovat' na medzinárodnej scéne, disponovat rozvahou a racionalitou pri riešení mnohých odborných, manažérskych či legislatívnych problémov na úrovni svojho pracoviska, ale aj na úrovni rôznych slovenských a medzinárodných rád, komisií či organizácií. Nikdy neváhala niest’ zodpovednost’ za seba a za iných, neúnavne presadzovala to, čo považovala za prospešné pre vedný odbor, pracovisko i akademickú komunitu, ktorú reprezentovala.

V lete 2020 oslávila Irena Medňanská krásne životné jubileum. Zoznam jej aktivít sa však v posledný deň roka 2020 náhle a nečakane uzatvoril. Pedagogická a odborná činnost’ v prospech výchovy budúcich generácií a v prospech slovenskej hudobnej kultúry nadobudla podobu definitívne ukončeného diela, čakajúceho na zhodnotenie a analytické sondy do jednotlivých oblastí jej odborného záujmu. Podstatnú čast’ svojho pracovného úsilia zasvätila tomu, aby sa hudba a pieseň stali súčastou života nastupujúcich generácií ako výraz estetického prežívania života, a cezeň smerovania k humanite, socializácii nielen v škole, rodine, ale aj spoločnosti. Jej vízia postavenia hudobnej výchovy v spoločnosti 21. storočia bola založená na presvedčení, že hudobná výchova chápaná ako aktívny celoživotný proces má nezastupitel'né miesto $v$ spoločnosti a jej poslaním je rozširovat’ sociálne a kultúrne horizonty detí a mládeže, nadobúdané práve uvedomovaním si širokej palety ludských hudobných skúseností.

Rozlúčka so zosnulou sa vzhladom na opatrenia súvisiace s pandémiou COVID-19 uskutočnila v úzkom rodinnom kruhu dňa 11. januára 2021 v Dome smútku v Prešove. Takto potichu a nenápadne odišla osobnost', ktorej aktívny život bol svedectvom toho, že vzdelanie, pracovitost' a priatel'stvo prinášajú spoločné hodnoty pre všetkých. Jej láskavý až materský prístup k študentom i kolegom (nezriedka okorenený prísnostou), jej živý záujem o problémy, s ktorými zápasia, ochota pomôct', jej múdrost’ a predvídavost’ mnohým z nich predurčili d’alšiu profesionálnu životnú dráhu. Iste, každý je v kolobehu života do vel'kej miery nahraditel'ný, ale po Irene Medňanskej tu zostáva prekvapivo smutný pocit, že bude velmi chýbat'... Ako osobnost' plná síl, energie a životných skúseností tu ešte chcela a mohla pre hudobnú výchovu vela vykonat. Zostáva po nej vyoraná brázda, spomienky, smútok v srdciach rodiny, blízkych priatel’ov i kolegov. Zostávajú tu však po nej aj mnohé silné inšpiratívne momenty navždy zapísané v našich životoch, ktorých bola súčastou. 